\title{
Bioactive Compounds from Selected Fruits Improve Quality and Oxidative Stability of Wallago Attu Fish Nuggets
}

Awlesh Kumar Vidyarthi', Subhasish Biswas, Rituparna Banerjee,

Gopal Patra, Gargi Mahapatra, Pankaj Waghaye, Raj Kumar Patel ${ }^{1}$

10.18805/IJAR.B-4506

\begin{abstract}
Background: This study determined the potential of fruit powder as natural preservatives in fish nuggets and indicated that fruit powder can successfully be incorporated in them without altering their acceptability. Additionally, a comparative study was carried out to find which fruit powder has the best antioxidant and antimicrobial activity, contributing towards the stability of the nuggets.

Methods: The guava (Psidium guajava L.) powder, bael (Aegle marmelos L.) pulp powder and dragon fruit (Hylocereus undatus L.) peel powders were incorporated at the rate of $1.5 \%(\mathrm{w} / \mathrm{w})$ respectively in fish nuggets and its effects on various physico-chemical, textural and sensory attributes of products were evaluated against control.

Result: Incorporation of fruit powder significantly $(P<0.05)$ increased emulsion stability, cooking yield, moisture, fat and protein percentage. Textural attributes were improved in treated nuggets, however overall acceptability scores were significantly $(P<0.05)$ higher for control as adjudged by the panelists. Fruit powder was found to slow down the lipid peroxidation of fish nuggets, as measured by thiobarbituric acid (TBA) value. They also maintained the microbial stability of nuggets upto 10 days during refrigerated storage $\left(4 \pm 1^{\circ} \mathrm{C}\right)$.
\end{abstract}

Key words: Anti-microbial activity, Anti-oxidative activity, Fish nuggets, Natural antioxidants, Shelf-life.

\section{INTRODUCTION}

Owing to its high nutritional quality and consumer demand, the 'Asian sheat catfish' or 'freshwater shark', Wallago attu is harvested across tropical Asia (Thella et al., 2018). This fast-growing freshwater catfish belongs to family Siluridae and is reported to be a very good source of protein, high content of water, lipid soluble vitamins, minerals and polyunsaturated fatty acids (PUFAs) of n-3 family (Gupta et al., 2015). The high moisture content (Lilabati and Viswanath, 1996) along with presence of unsaturated fatty acids makes them prone to microbial and chemical deterioration. Lipid oxidation, which affects sensory attributes such as taste, colour, texture and nutritional value, is a major limiting factor in the quality and acceptability of fish and fish products. Researchers are continuously exploring the potential of plants extracts and essential oils of herbs and spices as an alternative to synthetic preservatives in preservation of fish and fish products.

Guava (Psidium guajava L.), a 'super food' contains high amounts of dietary fibre, phenolic compounds, ellagic acid and anthocyanins, as well as other bioactive compounds (Miean and Mohamed, 2001). Many functional and bioactive compounds such as dietary fibre, carotenoids, phenolics, alkaloids, coumarins, flavonoids, terpenoids and other antioxidants are present in bael fruit (Aegle marmelos L. Correa), which is commonly found in the Indian Peninsula (Charoensidhi and Anprung, 2008). Dragon fruit (Hylocereus polyrhizus), which has recently gained popularity as a new source of food ingredients, is also high in antioxidants, fibre, vitamin $C$ and minerals. Till date there have been no reports of the use of guava, bael pulp, or dragon fruit peel in fish or
Department of Livestock Products Technology, West Bengal University of Animal and Fishery Sciences, Kolkata-700 037, West Bengal, India.

${ }^{1}$ ICAR-Indian Veterinary Research Institute, Izatnagar, Bareilly-243 122, Uttar Pradesh, India.

Corresponding Author: Awlesh Kumar Vidyarthi, ICAR-Indian Veterinary Research Institute, Izatnagar, Bareilly-243 122, Uttar Pradesh, India. Email: awilesh@gmail.com

How to cite this article: Vidyarthi, A.K., Biswas, S., Banerjee, R., Patra, G., Mahapatra, G., Waghaye, P. and Patel, R.K. (). Bioactive Compounds from Selected Fruits Improve Quality and Oxidative Stability of Wallago Attu Fish Nuggets. Indian Journal of Animal Research. DOI: 10.18805/IJAR.B-4506.

Submitted: 03-05-2021 Accepted: 03-08-2021 Online: 14-08-2021

fish products. Hence, the aim of this study was to determine the antioxidant and antimicrobial properties of fruit powder incorporation in improving quality and oxidative stability of fish nuggets stored at $4 \pm 1^{\circ} \mathrm{C}$, as well as to determine the best powder-product combination.

\section{MATERIALS AND METHODS}

\section{Raw material and chemicals}

The experiment was conducted at the Department of Livestock Products Technology, West Bengal University of Animal and Fishery Sciences, Kolkata, during 2018-2019. Catfish, procured from local market of Belgachia, Kolkata, were beheaded, eviscerated and cleaned laboratory. The fillet obtained was washed with cold water and then kept in 
deep freezer $\left(-18 \pm 2^{\circ} \mathrm{C}\right)$ till product preparation and further analysis. For the present study, whole guava fruit, bael pulp and peel of dragon fruits were separated and kept in the hot air oven $\left(50 \pm 1^{\circ} \mathrm{C}\right)$ for drying. Dried guava, bael pulp and dragon fruit peel were milled into a fine powder and sieved through a fine mesh with an average particle size of $<1.0$ $\mathrm{mm}$. The dried samples were aerobically packed in UV sterilised low density polyethylene containers and held at $4+1^{\circ} \mathrm{C}$ until further utilization. All the spice ingredients were cleaned, dried in the hot air oven at $60^{\circ} \mathrm{C}$ for $2 \mathrm{~h}$ and then ground using proportionate quantity to obtain dry spices mix for preparation of nuggets. All the chemicals of analytical grade were procured from standard firms viz., Himedia, Qualigens and Loba Chemie along with food grade commercial salt.

\section{Preparations of fish nuggets and analysis}

One $\mathrm{kg}$ formulation of emulsion was made for each treatment. The control formulation consisted of $70 \%$ minced fish, $10 \%$ refined mustard oil, $10 \%$ ice flakes, $1.6 \%$ salt, $0.3 \%$ sodium tripolyphosphate, $0.3 \%$ sugar, $1.8 \%$ dry spices powder, $3 \%$ condiments (onion and garlic $3: 1$ ) and $0.3 \%$ refined wheat flour. Sodium nitrite at $150 \mathrm{ppm}$ was also added to the above formulations. In treated formulations, guava powder (1.5\%), bael pulp powder (1.5\%), dragon fruit peel powder (1.5\%) powder were incorporated by replacing an equal amount minced fish in the control formulation. The emulsions were prepared in a bowl chopper (Talsa Ltd, Germany). Fish emulsion (approx.750 g) was placed into stainless steel moulds $(18 \times 12 \times 4 \mathrm{~cm})$, tightly packed and cooked in a steam oven $\left(100^{\circ} \mathrm{C}\right)$ at atmospheric pressure for $35 \mathrm{~min}$. The meat blocks were cooled to room temperature and cut into cubes of suitable sizes. About 200 $\mathrm{g}$ nuggets were packed in separate polyethylene pouches and stored at $4 \pm 1^{\circ} \mathrm{C}$ till further analysis.

\section{Analytical procedures}

The cooking yield per cent of the fish meat blocks was calculated as the difference in weight before and after cooking. The Emulsion stability of fish nuggets was determined as per procedure of Baliga and Madaiah (1971). The moisture, protein, fat and ash content of fruit powder and fish nuggets were determined by the methods of AOAC (1995). The $\mathrm{pH}$ of the emulsion and the nuggets were determined by the method suggested by Troutt et al. (1992). Thiobarbituric acid number of samples was measured according to method described by Witte et al. (1970) and Strange et al. (1977). Total plate count (TPC) and psychrophilic count were determined by APHA (1992) using pour plate method.

Texture Profile Analysis of the fish nuggets was determined (Bourne, 1978) on day 0 by TA-HDi Texture Analyzer (Stable Micro Systems,UK). Samples were thawed overnight and were allowed to attain a room temperature $\left(25^{\circ} \mathrm{C}\right)$. Central core of five pieces of each sample, each measuring $1.5 \mathrm{~cm} \times 1.5 \mathrm{~cm} \times 1.5 \mathrm{~cm}$, from the middle portion of each nuggets were used as the test samples. These were then placed on platform fixtures and compressed twice to $80 \%$ of the original height at a crosshead speed of $2 \mathrm{~mm} / \mathrm{s}$, through two cycle sequence at pre-test speed of $2 \mathrm{~mm} / \mathrm{s}$, post-test speed of $2 \mathrm{~mm} / \mathrm{s}$, keeping a distance of $8.5 \mathrm{~mm}$ and a trigger of $0.15 \mathrm{~N}$ using $50 \mathrm{~kg}$ load cell and $75 \mathrm{~mm}$ compression platen probe (P75).

The sensory parameters of the fish nuggets were evaluated by mean descriptive analysis method using 8 points hedonic scale (Keeton et al.1984) where 8 denoted extremely desirable and 1 unacceptable. A sensory panel of seven semi trained panelists was set up to evaluate the product for different quality attributes viz. color, flavor, tenderness, juiciness and overall acceptability.

\section{Statistical analysis}

All the data obtained during the present investigation were analyzed statistically to draw valid conclusion by using SPSS (Version 24.0) software. The data obtained were analyzed by randomized block design (4 treatments $\times 6$ no of samples) and subsequent one-way ANOVA analysis except storage study parameters were analyzed by complete randomized design for ( 3 treatment $\times 6$ no of samples $\times 5$ storage days) by two-way ANOVA. Further the significance between the data was compared by Tukey's Post Hoc Test by SPSS$24 \AA$ software package. A probability value of $p<0.05$ was described as significant and $p<0.01$ was noted as highly significant.

\section{RESULTS AND DISCUSSION}

\section{Proximate composition}

The $\mathrm{pH}$ and proximate composition of control as well as treated fish nuggets are presented in Table 1. Addition of fruit powder significantly $(\mathrm{p}<0.05)$ lowered the $\mathrm{pH}$ of fish nuggets compared to control samples. Fish nuggets treated with DFPP showed the lowest (6.16) $\mathrm{pH}$ value among all different fruit fibre treated nuggets and control possess highest (6.19) $\mathrm{pH}$ value. This could be due to the low $\mathrm{pH}$ values of fruit powder for example GP is a good source of ascorbic acid, which might have lowered the $\mathrm{pH}$ of the products. Addition of higher level of dragon fruit peel extract also lowered the $\mathrm{pH}$ of beef sausage (Manihuruk et al., 2017).

Incorporation of fruit powder significantly $(p<0.05)$ affected the moisture percentage of fish nuggets. The highest value $(68.13 \%)$ was recorded with fish nuggets treated with DFPP, followed by BPP and GP and control nuggets showed the lowest moisture percentage. The highest moisture percentage in fruit powder treated nuggets could be due to absorption of added water by the addition of powder during product preparation. Similar results were recorded in sheep meat emulsion with guava powder (Verma et al., 2013) and goat meat nuggets prepared with bael pulp residue (Das et al., 2015). 
Bioactive Compounds from Selected Fruits Improve Quality and Oxidative Stability of Wallago Attu Fish Nuggets

Addition of fruit powder significantly $(p<0.05)$ affected the protein percentage of fish nuggets. Fish nuggets added with DFPP possess highest (12.46) protein content and control showed lowest protein content as compared with different fruit fibre treated nuggets. According to Manihuruk et al. (2017), protein content of beef sausages was unaltered due to incorporation of red dragon fruit peel extract.

Incorporation of fruit powder significantly $(p<0.05)$ affected the fat percentage of nuggets. Fish nuggets treated with DFPP possessed the highest value of fat percentage (13.41) and nuggets treated with BPP recorded lowest value of (12.95) fat percentage. The high fat percentage of DFPP might have increased the fat content of nuggets in the present study. Beef sausages incorporated with red dragon fruit peel extract did not affect its fat percentage (Manihuruk et al., 2017).

\section{Thiobarbituric acid (TBA) values}

The TBA values ( $\mathrm{mg}$ malonaldehyde per $\mathrm{kg}$ ) of the treated fish nuggets were recorded on day $0,5,10,15$ and 20 day (Table 2). Incorporation of fruit powder significantly $(p<0.05)$ lowered the TBA value of fish nuggets. Although, the TBA values were increased in all the groups significantly $(p<0.05)$ throughout the storage period irrespective of any treatment, fish nuggets treated with GP had the lowest TBA value followed by DFPP, BPP and control. Polyphenolic extracts produced from a variety of plant-based products have been successfully used as natural antioxidant additives in the prevention of lipid oxidation in fish. Quince extracts $(8.9 \pm 0.4$ $\mathrm{mg}$ phenolics $/ \mathrm{mL}$ ) reduced peroxide levels and inhibited the formation of TBARS in the fat fraction of mackerel
(Scombrus scombrus) fillets during refrigeration $\left(4^{\circ} \mathrm{C}\right)$ (Fattouch et al., 2008).

\section{Microbiological parameters}

The total plate count, psychotropic count and coliform count $\left(\log _{10} \mathrm{cfu} / \mathrm{gm}\right)$ of the treated fish nuggets were presented in the Table 3 . The TPC of fish nuggets incorporated with different fruit fibre was significantly $(p<0.05)$ lower than control. The lowest total plate count was observed in DFPP (4.75) followed by GP and BPP. Psychotropic Count of different antioxidant fruit fibre treated fish nuggets were significantly $(p<0.05)$ lower than the control. No growth was recorded in treated nuggets till $5^{\text {th }}$ day of storage study. Fish nuggets treated with DFPP (3.43) showed lowest psychotropic count followed by GP and BPP. Incorporation of different fruit powder significantly $(p<0.05)$ lowered the total coliform count of fish nuggets. No growth was observed in treated nuggets till $7^{\text {th }}$ day. The lowest value of total coliform was observed in DFPP (1.32) treated fish nuggets followed by GP and BPP. Similar results were observed by Lin and Chou, (2004) who opined that combined effects of oregano and cranberry extracts in control Listeria growth in refrigerated fish system as compared to individual extract when the fish slices were kept at $4^{\circ} \mathrm{C}$ in refrigerated systems.

\section{Texture profile analysis}

Texture profile parameters of fish nuggets treated with different fruit powder were presented in Table 4. Addition of GP, BPP and DFPP to fish nuggets resulted in significant $(p<0.05)$ changes in hardness, springiness, cohesiveness, gumminess and chewiness values. Hardness and

Table 1: Physiochemical properties and proximate composition of fish nuggets.

\begin{tabular}{lcccc}
\hline \multirow{2}{*}{ Parameters } & \multicolumn{3}{c}{ Fish nuggets } & T2 \\
\cline { 2 - 5 } & Control & T1 & $65.99 \pm 0.07^{\mathrm{b}}$ & $68.13 \pm 0.02^{\mathrm{a}}$ \\
\hline Moisture & $65.80 \pm 0.02^{\mathrm{c}}$ & $66.00 \pm 0.07^{\mathrm{b}}$ & $12.37 \pm 0.01^{\mathrm{bc}}$ & $12.46 \pm 0.03^{\mathrm{a}}$ \\
Protein & $12.34 \pm 0.02^{\mathrm{c}}$ & $12.39 \pm 0.01^{\mathrm{b}}$ & $12.95 \pm 0.03^{\mathrm{c}}$ & $13.41 \pm 0.02^{\mathrm{a}}$ \\
Fat & $13.35 \pm 0.01^{\mathrm{b}}$ & $13.38 \pm 0.02^{\mathrm{ab}}$ & $2.36 \pm 0.02^{\mathrm{b}}$ & $2.56 \pm 0.04^{\mathrm{a}}$ \\
Ash & $2.30 \pm 0.01^{\mathrm{c}}$ & $2.51 \pm 0.02^{\mathrm{a}}$ & $6.18 \pm 0.01^{\mathrm{bc}}$ & $6.16 \pm 0.01^{\mathrm{c}}$ \\
pH & $6.19 \pm 0.01^{\mathrm{a}}$ & $6.17 \pm 0.01^{\mathrm{b}}$ & &
\end{tabular}

Mean \pm S.E. values bearing different superscripts in rows differ significantly $(p<0.05)$.

Control $=$ Fish nuggets without phytochemicals .

$\mathrm{T} 1=$ Fish nuggets with $1.5 \% \mathrm{GP}$.

T2 = Fish nuggets with 1.5\% BPP.

T3 = Fish nuggets with 1.5\% DFPP.

Table 2: TBA values (mg malonaldehyde/kg) fish nuggets incorporated with fruit powder during refrigerated storage $\left(4 \pm 1^{\circ} \mathrm{C}\right)$.

\begin{tabular}{lccccc}
\hline \multirow{2}{*}{ Treatments } & \multicolumn{5}{c}{ Storage day } \\
\cline { 2 - 6 } & 0 Day & $5^{\text {th }}$ day & $10^{\text {th }}$ day & $15^{\text {th }}$ day & $20^{\text {th }}$ day \\
\hline Control & $0.33 \pm 0.02^{\mathrm{fA}}$ & $0.52 \pm 0.01^{\mathrm{dA}}$ & $0.65 \pm 0.01^{\mathrm{cA}}$ & $1.08 \pm 0.01^{\mathrm{bA}}$ & $1.31 \pm 0.02^{\mathrm{aA}}$ \\
GP & $0.30 \pm 0.01^{\mathrm{fB}}$ & $0.42 \pm 0.01^{\mathrm{dB}}$ & $0.49 \pm 0.01^{\mathrm{cC}}$ & $0.66 \pm 0.01^{\mathrm{bC}}$ & $1.13 \pm 0.01^{\mathrm{aC}}$ \\
BPP & $0.30 \pm 0.01^{\mathrm{fB}}$ & $0.42 \pm 0.01^{\mathrm{dB}}$ & $0.52 \pm 0.01^{\mathrm{cB}}$ & $0.81 \pm 0.01^{\mathrm{bB}}$ & $1.15 \pm 0.01^{\mathrm{aB}}$ \\
DFPP & $0.29 \pm 0.01^{\mathrm{fB}}$ & $0.41 \pm 0.02^{\mathrm{dC}}$ & $0.51 \pm 0.01^{\mathrm{cB}}$ & $0.63 \pm 0.03^{\mathrm{bD}}$ & $1.14 \pm 0.01^{\mathrm{aC}}$ \\
\hline
\end{tabular}

Mean \pm S.E. values for all data (both rows and columns) differ significantly $(p<0.05)$. 
cohesiveness were significantly $(p<0.05)$ decreased except springiness, gumminess and chewiness which increased significantly $(p<0.05)$ in treatment groups. The lowest values for the hardness, gumminess and chewiness were recorded in nuggets treated with GP. When white grape dietary fibre concentrate was added to minced horse mackerel muscle, samples became smoother, less springy and cohesive (Sanchez-Alonso et al., 2007). The nature of dietary fiber ingredients in the present study and extent of their distribution in the meat batter could also have influenced the uniformity of three-dimensional protein network, thus the texture of the nuggets.

\section{Sensory properties}

The fish nuggets treated with GP, BPP and DFPP had significant $(p<0.05)$ differences in sensory properties viz. appearance, flavor, texture, tenderness and juiciness and overall acceptability scores. All the results observed during the present study were presented in Table 5. Fish nuggets treated with different fruit powder had significantly $(p<0.05)$ lower appearance, flavour, texture, tenderness and juiciness scores in comparison to control. Overall, the acceptability of control nuggets was significantly $(p<0.05)$ higher than other treatment groups. Elhadi et al. (2017) found that moringa leaf powder incorporated chicken patties had

Table 3: Microbiological parameters of fish nuggets incorporated with fruit powder during refrigerated storage $\left(4 \pm 1^{\circ} \mathrm{C}\right)$.

\begin{tabular}{|c|c|c|c|c|c|}
\hline \multirow{2}{*}{ Treatments } & \multicolumn{5}{|c|}{ Storage day } \\
\hline & 0 Day & 3 Day & 5 Day & 7 Day & 10 Day \\
\hline \multicolumn{6}{|c|}{ Total plate count (TPC) } \\
\hline Control & $2.04 \pm 0.01^{\mathrm{eA}}$ & $2.31 \pm 0.01^{\mathrm{dA}}$ & $2.75 \pm 0.01^{\mathrm{cA}}$ & $3.47 \pm 0.01^{\mathrm{bA}}$ & $4.15 \pm 0.01^{\mathrm{aA}}$ \\
\hline GP & $1.92 \pm 0.01^{\mathrm{eB}}$ & $2.27 \pm 0.01^{\mathrm{dB}}$ & $2.71 \pm 0.01^{\mathrm{cB}}$ & $3.20 \pm 0.01^{b c}$ & $4.09 \pm 0.01^{\mathrm{aAB}}$ \\
\hline BPP & $1.94 \pm 0.02^{\mathrm{eAB}}$ & $2.18 \pm 0.01^{\mathrm{dC}}$ & $2.71 \pm 0.01^{\mathrm{cB}}$ & $3.24 \pm 0.01^{\mathrm{bB}}$ & $4.15 \pm 0.06^{\mathrm{aA}}$ \\
\hline DFPP & $1.86 \pm 0.01^{\mathrm{eC}}$ & $2.09 \pm 0.01^{\mathrm{dD}}$ & $2.64 \pm 0.01^{\mathrm{cC}}$ & $3.17 \pm 0.02^{\mathrm{bD}}$ & $3.99 \pm 0.04^{\mathrm{aB}}$ \\
\hline \multicolumn{6}{|c|}{ Psychrophilic count } \\
\hline Control & ND & ND & ND & $2.05 \pm 0.01^{\mathrm{bA}}$ & $2.12 \pm 0.01^{\mathrm{aA}}$ \\
\hline GP & ND & ND & ND & $1.95 \pm 0.03^{\mathrm{bB}}$ & $1.98 \pm 0.01^{\mathrm{aC}}$ \\
\hline BPP & ND & ND & ND & $1.89 \pm 0.02^{\mathrm{bC}}$ & $2.05 \pm 0.03^{\mathrm{aB}}$ \\
\hline DFPP & ND & ND & ND & $1.79 \pm 0.02^{\mathrm{bD}}$ & $1.86 \pm 0.01^{\mathrm{aD}}$ \\
\hline \multicolumn{6}{|c|}{ Coliform count } \\
\hline Control & ND & ND & ND & ND & $1.65 \pm 0.06^{\mathrm{A}}$ \\
\hline GFP & ND & ND & ND & ND & $0.95 \pm 0.03^{\mathrm{B}}$ \\
\hline BPP & ND & ND & ND & ND & $0.96 \pm 0.01^{B}$ \\
\hline DFPP & ND & ND & ND & ND & $0.86 \pm 0.01^{\mathrm{C}}$ \\
\hline
\end{tabular}

N.D. - Not Detected.

Mean \pm S.E. values for all data (both rows and columns) differ significantly $(p<0.05)$.

Table 4: Texture profile analysis of fish nuggets incorporated with fruit powder.

\begin{tabular}{lcccc}
\hline Parameters & Control & GP & BPP & DFPP \\
\hline Hardness $\left(\mathrm{N} / \mathrm{cm}^{2}\right)$ & $45.29 \pm 0.002 \mathrm{a}$ & $41.61 \pm 0.003 \mathrm{~d}$ & $43.39 \pm 0.002 \mathrm{c}$ & $44.48 \pm 0.002 \mathrm{~b}$ \\
Springiness $(\mathrm{cm})$ & $0.65 \pm 0.001 \mathrm{~b}$ & $0.66 \pm 0.002 \mathrm{a}$ & $0.64 \pm 0.002 \mathrm{c}$ & $0.64 \pm 0.002 \mathrm{c}$ \\
Cohesiveness & $0.25 \pm 0.002 \mathrm{~b}$ & $0.26 \pm 0.001 \mathrm{a}$ & $0.25 \pm 0.001 \mathrm{~b}$ & $0.25 \pm 0.002 \mathrm{~b}$ \\
Gumminess $\left(\mathrm{N} / \mathrm{cm}^{2}\right)$ & $12.78 \pm 0.004 \mathrm{~b}$ & $10.15 \pm 0.003 \mathrm{~d}$ & $12.44 \pm 0.003 \mathrm{c}$ & $12.85 \pm 0.003 \mathrm{a}$ \\
Chewiness $(\mathrm{N} / \mathrm{cm})$ & $10.09 \pm 0.002 \mathrm{c}$ & $9.11 \pm 0.002 \mathrm{~d}$ & $9.76 \pm 0.002 \mathrm{a}$ & $10.71 \pm 0.002 \mathrm{~b}$ \\
\hline
\end{tabular}

Mean + S.E. values with different superscripts in rows differ significantly $(p<0.05)$.

Table 5: Sensory parameters of fish nuggets incorporated with fruit powder.

\begin{tabular}{lcccc}
\hline Parameters & Control & GP & BPP & DFPP \\
\hline Color & $6.11 \pm 0.28^{\mathrm{a}}$ & $5.85 \pm 0.35^{\mathrm{c}}$ & $5.79 \pm 0.23^{\mathrm{d}}$ & $5.91 \pm 0.21^{\mathrm{b}}$ \\
Flavor & $6.08 \pm 0.39^{\mathrm{a}}$ & $5.91 \pm 0.26^{\mathrm{b}}$ & $5.94 \pm 0.38^{\mathrm{ab}}$ & $5.25 \pm 0.20^{\mathrm{c}}$ \\
Texture & $6.52 \pm 0.36^{\mathrm{a}}$ & $6.48 \pm 0.37^{\mathrm{ab}}$ & $6.37 \pm 0.33^{\mathrm{b}}$ & $5.98 \pm 0.51^{\mathrm{c}}$ \\
Tenderness & $6.15 \pm 0.27^{\mathrm{a}}$ & $6.04 \pm 0.39^{\mathrm{b}}$ & $5.14 \pm 0.23^{\mathrm{a}}$ & $5.69 \pm 0.48^{\mathrm{c}}$ \\
Juiciness & $5.51 \pm 0.25^{\mathrm{a}}$ & $5.10 \pm 0.23^{\mathrm{c}}$ & $5.41 \pm 0.21^{\mathrm{b}}$ & $4.96 \pm 0.33^{\mathrm{d}}$ \\
Overall acceptability & $5.92 \pm 0.38^{\mathrm{a}}$ & $5.75 \pm 0.25^{\mathrm{b}}$ & $5.83 \pm 0.38^{\mathrm{ab}}$ & $5.77 \pm 0.32^{\mathrm{c}}$ \\
\hline
\end{tabular}

Mean \pm S.E. values with different superscripts in rows differ significantly $(p<0.05)$. 
significantly lower colour, taste, tenderness and juiciness scores than the control.

\section{CONCLUSION}

Guava, bael pulp and dragon fruit peel powder are rich sources of phenolic compounds, total carotenoids and vitamin $C$. Fruit powder can be used as a functional ingredient in emulsion-based fish products to change their physicochemical properties and improve textural parameters without affecting their acceptability. Fruit powder's strong antioxidant and antimicrobial properties can be used in the meat industry to maintain the microbial stability and minimise oxidation of meat and meat products throughout storage upto 10-15 days.

\section{ACKNOWLEDGEMENT}

The first author is thankful to Indian Council of Agricultural Research, New Delhi and acknowledges the financial assistance in the form of Fellowship for carrying out the research work. He is also grateful to Managing Director, West Bengal Livestock Development Corporation Ltd. for providing working facilities.

\section{REFERENCES}

AOAC. (1995). Association of Analytical Chemists, Official method of Analysis. 15 ${ }^{\text {th }}$ Edition, Washington D.C; USA.

APHA. (1992). APHA Compendium of methods for the microbiological examination ( $3^{\text {rd }}$ ed.), American Public Health Association, Washington (1992) pp. 105-119, 325-367, 371-415, 451469 and $637-658$

Baliga, B.R. and Madaiah, N. (1971). Preparation of mutton sausages. Journal of Food Science. 36(4): 607-610.

Bourne, M.C. and MC, B. (1978). Texture Profile Analysis.

Charoensiddhi, S. and Anprung, P. (2008). Bioactive compounds and volatile compounds of Thai bael fruit [Aegle marmelos (L.) Correa] as a valuable source for functional food ingredients. International food Research journal. 15(3). 287-295.

Das, A.K., Rajkumar, V. and Verma, A.K. (2015). Bael pulp residue as a new source of antioxidant dietary fiber in goat meat nuggets. Journal of Food Processing and Preservation. 39(6): 1626-1635.

Elhadi, D.A., Elgasim, E.A. and Mohamed Ahmed, I.A. (2017). Microbial and oxidation characteristics of refrigerated chicken patty incorporated with moringa (Moringa oleifera) leaf powder. CyTA-Journal of Food. 15(2): 234-240.

Fattouch, S., Sadok, S., Raboudi Fattouch, F. and Slama, M.B. (2008). Damage inhibition during refrigerated storage of mackerel (Scomber scombrus) fillets by a presoaking in quince (Cydonia oblonga) polyphenolic extract. International Journal of Food Science and Technology. 43(11): 20562064.
Gupta, V., Gandotra, R., Koul, M., Gupta, S. and Parihar, D.S. (2015). Quality evaluation and shelf-life assessment of raw and value added fish product (fish cutlet) of Wallago attu during frozen storage conditions (-12 C). International Journal of Fisheries and Aquatic Studies. 2(6): 243-247.

Keeton, J.T., Foegeding, E.A. and Patana Anake, C. (1984). A comparison of nonmeat proteins, sodium tripolyphosphate and processing temperature effects on physical and sensory properties of frankfurters. Journal of Food Science. 49(6): 1462-1465.

Lilabati, H. and Vishwanath, W. (1996). Nutritional quality of fresh water catfish (Wallago attu) available in Manipur, India. Food Chemistry. 57(2): 197-199.

Lin, Y.D. and Chou, C.C. (2004). Effect of heat shock on thermal tolerance and susceptibility of Listeria monocytogenes to other environmental stresses. Food microbiology. 21(5): 605-610.

Manihuruk, F.M., Suryati, T. and Arief, I.I. (2017). Effectiveness of the red dragon fruit (Hylocereus polyrhizus) peel extract as the colorant, antioxidant and antimicrobial on beef sausage. Media Peternakan. 40(1): 47-54.

Miean, K.H. and Mohamed, S. (2001). Flavonoid (myricetin, quercetin, kaempferol, luteolin and apigenin) content of edible tropical plants. Journal of agricultural and food chemistry. 49(6): 3106-3112.

Sánchez-Alonso, I., Jiménez-Escrig, A., Saura-Calixto, F. and Borderías, A.J. (2007). Effect of grape antioxidant dietary fibre on the prevention of lipid oxidation in minced fish: Evaluation by different methodologies. Food chemistry. 101(1): 372-378.

Strange, E.D., Benedict, R.C., Smith, J.L. and Swift, C.E. (1977). Evaluation of Rapid Tests for Monitoring Alterations in Meat Quality During Storage. Journal of Food Protection. 40(12): 843-847.

Thella, R.U.F.U.S., Dahanukar, N.E.E.L.E.S.H., Eldho, P.S., Ali, A.N.V.A.R. and Raghavan, R.A.J.E.E.V. (2018). Population dynamics of Wallago attu (Bloch and Schneider 1801) (Osteichthyes, Siluridae) in three small rivers of Southern India. Asian Fisheries Science. 31: 172-178.

Troutt, E.S., Hunt, M.C., Johnson, D.E., Claus, J.R., Kastner, C.L. and Kropf, D.H. (1992). Characteristics of Low-Fat Ground Beef Containing Texture-Modifying Ingredients. Journal of Food Science. 57(1): 19-24.

Verma, A.K., Rajkumar, V., Banerjee, R., Biswas, S. and Das, A.K. (2013). Guava (Psidium guajava L.) powder as an antioxidant dietary fibre in sheep meat nuggets. AsianAustralasian journal of animal sciences. 26(6): 886.

Witte, V.C., Krause, G.F. and Bailey, M.E. (1970). A New Extraction Method for Determining 2-Thiobarbituric Acid Values of Pork and Beef During Storage. Journal of Food Science. 35(5): 582-585. 